\title{
Perception of Nursing Staff about the Effectiveness of Staff Nurse's Development Program.
}

\author{
Magda A. EL Mola , Dr. Eman A. Etway \& Sawsan E. ELShafey \\ Nursing Administration department, Faculty of Nursing- Cairo University
}

\begin{abstract}
Staff development in professional is generally those of preparing staff to apply the previously acquired knowledge to patient care situation and acquire the kinds of professional and personal skills, attitudes and valuable thoughts essential for entering the health care system. The aim of the current study was to assess the perception of nursing staff about the effectiveness of staff nurse's development program. An exploratory descriptive research design was utilized to answer the question of what the perception of nursing staff about the effectiveness of staff nurse's development program. A convenient sample included (150) Staff nurses and nursing staff working in intensive care units. The study findings showed a statistically significant difference between staff nurses and nursing staff perception, and the nursing staff had the lowest perception of the effectiveness of staff nurse's development program than staff nurses. The study recommendations were regular staff development courses to update the staff knowledge and skills and providing guidance for them, added management training programs as ( leadership skills training, Decision-making and problem-solving training, trains participant on how to control documents ) to staff development program , follow-up the nursing staff's performance by the training team, provide enough facilities, supplies, and equipment to enable the staff to practice what they were learned efficiently
\end{abstract}

Key words: The staff nurses, nursing staff, staff development program.

\section{Introduction}

The major purposes of staff development in professional are generally those of preparing staff to apply the previously acquired knowledge and assist staff transferring theory into practice and improve their clinical decision-making skills. (National league for Nursing, 2004\& Mizell, 2010)

Nursing is the protection, promotion, and optimization of health and abilities, prevention of illness and injury, alleviation of suffering through the diagnosis and treatment of human response, and advocacy in the care of individuals, families, communities, and populations (ANA, 2010, ANA, 2014).

Nursing staff is people who are educated and licensed in the practice of nursing; one who are concerned with "the diagnosis and treatment of human responses to actual or potential health problems" (American Nurses Association, 2014).

Staff development programs offer training or continuing education to staff nurses, help them plan their own professional growth. Organizations that support staff 
development expect to benefit from having staff nurses with greater skills and deeper expertise. Staff development can include inhouse training, tuition assistance or policies that make it easier for staff to take continuing education classes. Effective staff development is more than just mentoring or holding seminars. Ideally, it takes an individualized approach in which the organization talks to staff nurses, find out their goals and builds a plan to achieve them. Performance reviews are often a starting point. A supervisor reviews the staff nurses performance and then discusses with them where they can grow in the coming year, and what it will take to make that happen. For example, the supervisor might arrange for the staff to cross-train with other workers to gain new skills, or authorize paying for them to take a professional certification course, (Sherman, 2014).

\section{Significance of the study}

Nursing staff development training program helps in improving the quality of work and work-life. Healthy work environment helps to build good employee relationship so that individual goals bring into line with organizational goal. Also improving the morale of the workforce, help the organization gets more effective decisionmaking and problem-solving, helps in understanding and carrying out organizational policies, helps in developing leadership skills, motivation, loyalty, better attitudes, and other aspects that successful workers and managers usually display (Swigard, 2010). Assessing the perception of nursing staff about the effectiveness of nurse's staff development program will help to provide necessary data to overcome the gap between what is already done and what it should be done to improve the outcome.

\section{Methods of staff development:}

Training; a well-designed training program that maximizes learning before, during and after instruction translates into positive, lasting changes on the job performance.. (Alberta, 2014)

Self-directed learning ; puts individual staff in control of their own learning, allowing for personal differences in learning styles and encouraging ownership of the learning process. (ANA, 2010,Alberta, 2014)

Coaching and mentoring; Demonstrated benefits of these include improved quality and quantity of work; transfer of learning and, for staff, improved communication, and problem-solving skills. Effective coaching and mentoring programs depend on the skills and personality of the mentor or coach, adequate time for coaching and mentoring and established timelines and goals. (Alberta, 2014)

Employee promotion; Promoting someone to a position of greater responsibility is a traditional way of rewarding good performance, developing employee skills and retaining valued employees. (Alberta, 2014)

Job improvement; increases the staff authority or responsibility within their current position. Examples include committee work, special assignments or serving on cross-functional teams. Increases interest and motivation by allowing staff to try new skills, build new relationships and explore new specialization. (ANA, 2010 , Alberta, 2014)

Job rotation and cross-training or Lateral moves; Job rotation move staff through one or more different positions. A lateral move may offer new challenges or encourage the development of different skills for a staff who may not necessarily want to be increased responsibility this increases flexibility and communication among work units. (Alberta, 2014) 
Job aids; Job aids include checklists; tip sheets, wallet cards, posters, pictures, code lists, flow charts, and diagrams-anything that offers on-the-spot practical help or reminders. (Alberta, 2014)

Staff development advantage and benefits are staff nurse's job satisfaction, more self-confidence, more self-sufficiency and job independence, better decision making, leadership skills, smoother adjustment to staff nurse's role and finally better integration for the clinical nursing experience. On the other hand program improve recruitment, retention of new graduate and also better potential care in the hospital which consider as a benefit to hospital (Alberta, 2014) and other benefits are awareness and sensitivity to the needs of patient, more realistic expectation for staff nurses recognition of staff knowledge, skills and clinical expertise and improve staff morale which lead to decrease staff shortage and lower turnover rate and renewed staff continuing education, it enables the staff nurses to integrate the knowledge and skills associated with caring for patient, as well as giving them the opportunity to internalize the role of nurses as caregivers (Allen, 2014 ).

\section{Staff development programs and Performance Improvement}

Quality and performance improvement is a dynamic, interdisciplinary process that strives to achieve the outcomes The departments of nursing quality and performance improvement plan is aligned with the goals outlined in quality and safety performance improvement program and prides itself as a staff-driven program that showcases the excellence that is nursing. provide a coordinated system that continuously assesses and evaluates quality in patient care and nursing practice through a regular review and benchmark data, develop, implement, and evaluate unit and service performance improvement efforts, Promote a forum for the development, discussion, and implementation of hospitals center-wide, interdepartmental, and intradepartmental performance improvement efforts(Medical center ,2013).

\section{Staff development programs and Documentation}

Documentation in the individual's record facilitates communication among professionals from different disciplines and on different shifts. It provides information so that healthcare providers can deliver care in a coordinated manner; Information in the individual's record is a source of data for quality assurance and peer review programs, is based in part on the Quality and timeliness of nursing care reflected in the individual's record.( Scott,2006)

Document the individual's record serves as a legal protection document that Identified health problems should be reviewed on a regular and timely basis, documentation should include the status of the identified problems until they are resolved, When the problem is resolved, it should be noted, normal and abnormal findings should be included in comprehensive assessment reports. (Scott,2006).

\section{Aim of study: -}

The aim of current study was to assess perception of nursing staff about the effectiveness of staff nurse's development program

Research

design: - Descriptive exploratory design was adopted to fulfill the purpose of the study

\section{Subjects and Methods}

Sample: - For the purpose of this study two samples had been used, total sample (150) distributed as the following First sample included convenient staff nurses works in the intensive care units at New Kasser el-Ainy teaching hospital and had more than one year of experience and 
attended staff development programs (133) and accepted to participate in the study \& The second sample included convenient nursing staff who accepted to participate in the study (head nurses, assistant head nurses, and supervisor) who had more than 5 years of experience and they evaluate and are in direct contact with staff nurses (17) all Bachelors of nursing .

Setting :- This study was conducted at New Kasser el-Ainy teaching hospital which affiliated to Cairo University in the intensive care units:-

\section{Ethical consideration: -}

An official permission was granted from the Faculty of Nursing research ethical committee, Cairo University. The investigator emphasized that voluntary participation; confidentiality and anonymity of their responses are assured.

Tools of data collection: - For the purpose of the study structured questionnaire sheet was utilized. First part: -Back ground data sheet: It consisted of socio-demographic data and work related data. \& Second part: Structured questionnaire sheet to assess the perception of the effectiveness of staff nurse's development program

Pilot study: - It carried out on a sample of (15) from nursing staff selected randomly from the different intensive care units to check and ensure the clarity of the Arabic

Procedure: - Once permission granted to precede with the proposed study a letter from the faculty of nursing were sent to the director of Cairo University hospital seeking their approval for collecting data, each subject was contacted by the investigator to explain the nature and purpose of the study. Data was collect from all intensive care nursing staff at new kasser- Elaine teaching hospital.. The duration for collection was four months from February to May 2015

Statistical Design: - Data were analyzed and tabulated using Statistical Package for Social Science (SPSS windows) version 20. Numerical data were expressed as mean \pm SD. Qualitative data were expressed as frequency and percentage. Relations between different numerical variables were tested used t-test. Probability (p-value) less than 0.05 was considered significant and less than 0.001 was considered as highly significant, One way analysis of variance (ANOVA ) for correlation between demographic data and all dimensions

\section{Results}

The results of the current study were presented in the comparison between the perception 
(N=150)

Table (1): Percentage description of the studied sample's socio-demographic data

\begin{tabular}{|l|l|l|l|l|l|}
\hline \multirow{3}{*}{$\begin{array}{l}\text { Demographic } \\
\text { characteristics }\end{array}$} & \multicolumn{2}{l|}{$\begin{array}{l}\text { staff nurses } \\
(\mathrm{N}=133)\end{array}$} & \multicolumn{2}{l|}{ nursing staff (N=17) } \\
\cline { 2 - 6 } & & No. & $\%$ & No. & $\%$ \\
\hline \multirow{5}{*}{ Qualification } & Technical school of Nursing & 93 & 69.9 & 0 & 0.0 \\
\cline { 2 - 6 } & Technical institute of Nursing & 32 & 24.1 & 0 & 0.0 \\
\cline { 2 - 6 } & Bachelor of Nursing & 8 & 6.0 & 17 & 100.0 \\
\hline \multirow{4}{*}{$\begin{array}{l}\text { Years of } \\
\text { experience }\end{array}$} & $2>5$ & 22 & 16.5 & 0 & 0.0 \\
\cline { 2 - 6 } & $5>10$ & 33 & 24.8 & 3 & 17.6 \\
\cline { 2 - 6 } & $10>15$ & 32 & 24.1 & 5 & 29.4 \\
\cline { 2 - 6 } & $>15$ & 46 & 34.6 & 9 & 52.9 \\
\hline \multirow{5}{*}{ raining courses } & $\begin{array}{l}\text { CPR - infection control - } \\
\text { medication awareness }\end{array}$ & 29 & 21.9 & NA & NA \\
\cline { 2 - 6 } & $\begin{array}{l}\text { CPR - infection control - } \\
\text { on charge ( responsible ) training }\end{array}$ & 15 & 11.3 & NA & NA \\
\cline { 2 - 6 } & $\begin{array}{l}\text { CPR - infection control - dealing } \\
\text { with patient }\end{array}$ & 6 & 4.5 & NA & NA \\
\cline { 2 - 6 } & CPR - infection control & 49 & 36.8 & NA & NA \\
\cline { 2 - 6 } & CPR - infection control -ECG & 34 & 25.6 & NA & NA \\
\hline
\end{tabular}

NA $=$ not applicable

Table (1): showed that the highest percent $(69.9 \%)$ of the staff nurses graduated from Technical school of Nursing, $(24.1 \%)$ graduated from Technical institute of Nursing and only (6\%) bedside nurses graduated from Bachelor of Nursing. While the nursing staff showed that all (100\%) graduated from Bachelor of Nursing.

The highest percent $(34.6 \%)$ of the staff nurses had more than 15 years of experience, the lowest $(16.5 \%)$ had $2>5$ Years of experience and the rest of the sample had experience between 5 and 15 years of experience, while The nursing staff had the highest percent $(52.9 \%)$ more than 15 years of experience, $17.6 \%$ had 5>10 years of experience and the rest of the sample had experienced between 10 and 15 years. Also, the majority (36.8\%) of the staff nurses attended training programs CPR-infection control and ( 25.6) attended programs about, CPR ,infection control and EGG . while The nursing staff was not attended any training programs. 
Table (2): Mean score of perceptions of studied sample about the nursing development programs effectiveness dimension. $(\mathrm{N}=150)$

\begin{tabular}{|c|c|c|c|c|c|}
\hline No. & Nursing development programs effectiveness & $\begin{array}{l}\quad \text { staff } \\
\text { nurses } \\
(\mathrm{N}=133) \\
\text { Mean } \\
\pm \mathrm{SD}\end{array}$ & $\begin{array}{c}\text { nursing } \\
\text { staff } \\
(\mathrm{N}=17) \\
\text { Mean } \\
\pm \mathrm{SD}\end{array}$ & $\mathrm{t}$-value & P-value \\
\hline 1 & $\begin{array}{l}\text { There is a continuous renewal in the activities and } \\
\text { training methods in the hospital. }\end{array}$ & $\begin{array}{l}3.496 \\
\pm 0.997\end{array}$ & $\begin{array}{l}3.059 \\
\pm 1.029\end{array}$ & 1.66 & 0.0998 \\
\hline 2 & $\begin{array}{l}\text { The follow-up to the nursing team's performance was } \\
\text { constant by the training team. }\end{array}$ & $\begin{array}{l}3.346 \\
\pm 1.01\end{array}$ & $\begin{array}{l}2.235 \\
\pm 1.033\end{array}$ & 4.1859 & $0.0001 *$ \\
\hline 3 & $\begin{array}{l}\text { The followed training method in the hospital has } \\
\text { achieved the training program goals. }\end{array}$ & $\begin{array}{l}3.1867 \\
\pm 0.915\end{array}$ & $\begin{array}{l}3.0588 \\
\pm 0.899\end{array}$ & 0.551 & 0.5825 \\
\hline 4 & $\begin{array}{l}\text { The necessary possibilities for the use of modern } \\
\text { technology and training methods are available in the } \\
\text { hospital }\end{array}$ & $\begin{array}{l}2.663 \\
\pm 1.144\end{array}$ & $\begin{array}{l}2.412 \\
\pm 0.87\end{array}$ & 1.0784 & 0.2826 \\
\hline 5 & $\begin{array}{l}\text { The objectives of the training at the hospital were } \\
\text { determined in light of the actual needs of the nursing } \\
\text { staff. }\end{array}$ & $\begin{array}{l}3.36 \\
\pm 0.97\end{array}$ & $\begin{array}{l}2.9412 \\
\pm 1.088\end{array}$ & 1.5117 & 0.1327 \\
\hline 6 & $\begin{array}{l}\text { There is catalyst (tangible or intangible) to attend } \\
\text { training programs. }\end{array}$ & $\begin{array}{l}2.2333 \\
\pm 1.2\end{array}$ & $\begin{array}{l}2.1765 \\
\pm 1.13\end{array}$ & 0.1935 & 0.8469 \\
\hline 7 & $\begin{array}{l}\text { The content of the training programs were determined } \\
\text { on the basis of different abilities of the nursing team. }\end{array}$ & $\begin{array}{l}3.067 \\
\pm 1.001\end{array}$ & $\begin{array}{l}2.588 \\
\pm 0.94\end{array}$ & 1.96 & 0.05 \\
\hline 8 & $\begin{array}{l}\text { The duration of the training was in a timely and the } \\
\text { specific hours for training. }\end{array}$ & $\begin{array}{l}3.20 \\
\pm 0.96\end{array}$ & $\begin{array}{l}3.24 \\
\pm 1.25\end{array}$ & 0.095 & 0.924 \\
\hline 9 & $\begin{array}{l}\text { There is a relationship between nursing performance } \\
\text { improvements and attend training programs. }\end{array}$ & $\begin{array}{l}3.52 \\
\pm 1.01479\end{array}$ & $\begin{array}{l}3.00 \\
\pm 1.17260\end{array}$ & 1.75 & 0.0828 \\
\hline 10 & $\begin{array}{l}\text { Attending of the training programs affect on the } \\
\text { nursing job satisfaction. }\end{array}$ & $\begin{array}{l}3.547 \\
\pm 2.64 \\
\end{array}$ & $\begin{array}{l}3.294 \\
\pm 1.15999\end{array}$ & 0.696 & 0.487 \\
\hline 11 & $\begin{array}{l}\text { Attending of the training programs affect on the } \\
\text { nursing loyalty }\end{array}$ & $\begin{array}{l}3.4533 \\
\pm 1.021\end{array}$ & $\begin{array}{l}3.1765 \\
\pm 1.074 \\
\end{array}$ & 1.006 & 0.316 \\
\hline 12 & $\begin{array}{l}\text { Attending nursing training programs increase the } \\
\text { patient's satisfaction. }\end{array}$ & $\begin{array}{l}3.527 \\
\pm 2.67651\end{array}$ & $\begin{array}{l}2.647 \\
\pm 0.78591\end{array}$ & 2.929 & $0.0039 *$ \\
\hline 13 & $\begin{array}{l}\text { Attending the nursing training programs increase the } \\
\text { medical team satisfaction for the nursing } \\
\text { performance. }\end{array}$ & $\begin{array}{l}3.353 \\
\pm 0.991 \\
\end{array}$ & $\begin{array}{l}3.00 \\
\pm 1.061 \\
\end{array}$ & 1.3027 & 0.1947 \\
\hline 14 & $\begin{array}{l}\text { Attending the nursing training programs affects on } \\
\text { increase the ability to solve problems and challenges. }\end{array}$ & $\begin{array}{r}3.541 \\
\pm 1.008 \\
\end{array}$ & $\begin{array}{r}2.882 \\
\pm 1.219 \\
\end{array}$ & 2.1367 & $0.0343 *$ \\
\hline 15 & $\begin{array}{l}\text { Immediate superiors support the nursing team in } \\
\text { attending of the training programs. }\end{array}$ & $\begin{array}{l}3.493 \\
\pm 1.008\end{array}$ & $\begin{array}{l}4.059 \\
\pm 1.029\end{array}$ & 0.3782 & 0.7059 \\
\hline 16 & $\begin{array}{l}\text { Training programs are considered successful from } \\
\text { your point of view. }\end{array}$ & $\begin{array}{l}3.547 \\
\pm 0.886\end{array}$ & $\begin{array}{l}3.235 \\
\pm 0.97 \\
\end{array}$ & 1.2582 & 0.2103 \\
\hline \multicolumn{2}{|c|}{ Total } & $\begin{array}{c}3.302 \\
\pm 0.676 \\
\end{array}$ & $\begin{array}{l}3.302 \\
\pm 0.676 \\
\end{array}$ & $\begin{array}{l}2.9375 \\
0.7352\end{array}$ & 0.0543 \\
\hline
\end{tabular}

SD: standard deviation *significant $<0.05$ levels 
Table (2): showed that, there was statistical significant difference of perception between staff nurses and nursing staff

Table (3): Mean score of perceptions of studied sample about the effectiveness of nursing development programs on the nursing performance dimension $(\mathrm{N}=150)$

\begin{tabular}{|c|c|c|c|c|c|}
\hline \multirow[t]{2}{*}{ No. } & \multirow[t]{2}{*}{$\begin{array}{l}\text { The effectiveness of the nursing development } \\
\text { programs on nursing performance }\end{array}$} & $\begin{array}{l}\text { staff nurses } \\
(\mathrm{N}=133)\end{array}$ & $\begin{array}{l}\text { nursing staff } \\
(\mathrm{N}=17)\end{array}$ & \multirow[t]{2}{*}{$\mathrm{t}$-value } & \multirow[t]{2}{*}{ p-value } \\
\hline & & $\begin{array}{l}\text { Mean } \\
\text { SD }\end{array}$ & $\begin{array}{l}\text { Mean } \\
\text { SD }\end{array}$ & & \\
\hline 1 & $\begin{array}{l}\text { It Increased the professional responsibility } \\
\text { and accountability and efficiency of the } \\
\text { nursing performance. }\end{array}$ & $\begin{array}{l}3.6097 \\
\pm 0.851\end{array}$ & $\begin{array}{l}3.2353 \\
\pm 0.971\end{array}$ & 1.5184 & 0.1310 \\
\hline 2 & $\begin{array}{l}\text { It Improves the performance that builds on } \\
\text { the nursing science and knowledge. }\end{array}$ & $\begin{array}{l}3.787 \\
\pm 0.815\end{array}$ & $\begin{array}{l}3.471 \\
\pm 1.007\end{array}$ & 1.2429 & 0.2159 \\
\hline 3 & $\begin{array}{l}\text { It supports overall quality application to } \\
\text { improve the quality of nursing care. }\end{array}$ & $\begin{array}{l}3.667 \\
\pm 0.904\end{array}$ & $\begin{array}{l}3.177 \\
\pm 1.1851\end{array}$ & 1.6454 & 0.1020 \\
\hline 4 & It increases the leadership skills. & $\begin{array}{l}3.497 \\
\pm 0.90054\end{array}$ & $\begin{array}{l}2.941 \\
\pm 0.96635\end{array}$ & 2.249 & $0.0260 *$ \\
\hline 5 & $\begin{array}{l}\text { It encourage attending developing programs } \\
\text { and participating effectively }\end{array}$ & $\begin{array}{l}3.387 \\
\pm 1.035\end{array}$ & $\begin{array}{l}2.88 \\
\pm 1.054\end{array}$ & 1.86 & 0.065 \\
\hline 6 & $\begin{array}{l}\text { It help to use of knowledge and skills gained } \\
\text { in the development of nursing care. }\end{array}$ & $\begin{array}{l}3.587 \\
\pm 0.9497 \\
\end{array}$ & $\begin{array}{l}3.29 \\
\pm 0.986\end{array}$ & 1.1577 & 0.2488 \\
\hline \multicolumn{2}{|c|}{ Total } & $\begin{array}{l}3.607 \\
\pm .742 \\
\end{array}$ & $\begin{array}{l}3.167 \\
\pm .835 \\
\end{array}$ & 2.069 & $0.0403 *$ \\
\hline
\end{tabular}

SD: standard deviation *significant $<0.05$ levels

Table (3): showed that, there was statistical significant difference in the Total mean score ( $\mathrm{t}$ $2.068 \mathrm{p} \leq 0.04)$

Table (4): Mean score of perceptions of studied sample about the effectiveness of nursing development programs on documents and recordings dimension.( $N=150)$

\begin{tabular}{|c|c|c|c|c|c|}
\hline \multirow[t]{2}{*}{ No. } & \multirow[t]{2}{*}{$\begin{array}{l}\text { The effectiveness of nursing development } \\
\text { programs on documents and recordings }\end{array}$} & $\begin{array}{l}\text { staff nurses } \\
(\mathrm{N}=133)\end{array}$ & $\begin{array}{l}\text { nursing } \\
\text { staff } \\
(\mathrm{N}=17)\end{array}$ & \multirow[t]{2}{*}{ t-value } & \multirow[t]{2}{*}{ p-value } \\
\hline & & $\begin{array}{l}\text { Mean } \\
\text { SD }\end{array}$ & $\begin{array}{l}\text { Mean } \\
\text { SD }\end{array}$ & & \\
\hline 1 & $\begin{array}{l}\text { It Increases the integration of documentation } \\
\text { requirements to increase the quality service } \\
\text { provided. }\end{array}$ & $\begin{array}{l}3.313 \\
\pm 0.96\end{array}$ & $\begin{array}{l}2.94 \\
\pm 1.088\end{array}$ & 1.3444 & 0.1809 \\
\hline 2 & $\begin{array}{l}\text { There is a noticeable improvement in the nursing } \\
\text { recordings after attending training programs. }\end{array}$ & $\begin{array}{l}3.283 \\
\pm 0.918\end{array}$ & $\begin{array}{l}2.706 \\
\pm 0.849\end{array}$ & 2.6159 & $0.0098^{*}$ \\
\hline 3 & $\begin{array}{l}\text { It Improve the writing quality for chronicling } \\
\text { documentation and sequentially by time. }\end{array}$ & $\begin{array}{l}3.334 \\
\pm 1.001\end{array}$ & $\begin{array}{l}2.824 \\
\pm 1.015\end{array}$ & 1.9575 & 0.0522 \\
\hline 4 & $\begin{array}{l}\text { It Improve the nursing documentation to increase } \\
\text { safety and legal protection. }\end{array}$ & $\begin{array}{l}3.96 \\
\pm 1.072\end{array}$ & $\begin{array}{l}2.882 \\
\pm 0.993\end{array}$ & 4.1756 & $0.0001^{*}$ \\
\hline 5 & It trains participant on how to control documents. & $\begin{array}{l}3.573 \\
\pm 1.000\end{array}$ & $\begin{array}{l}2.706 \\
\pm 0.849\end{array}$ & 3.883 & $0.0002^{*}$ \\
\hline Tota & & $\begin{array}{l}3.411 \\
\pm .829\end{array}$ & $\begin{array}{l}2.812 \\
\pm .698\end{array}$ & 3.255 & $0.0014 *$ \\
\hline
\end{tabular}

SD: standard deviation $\quad *$ significant $<0.05$ levels 
Table (4): showed that, there was highly statistically significant difference in the Total mean score (t $3.2547 \mathrm{p} \leq 0.0014) \&$ in items $2,4,5$

\section{Discussion}

The present study was conducted to assessment the Perception of nursing staff about the effectiveness of staff nurse's development program

The study sample was two sample (staff nurses and nursing staff ), staff nurses majority of them graduated from a technical school of nursing followed by the technical institute of nursing and last bedside nurses graduated from bachelor of nursing while all nursing staff graduated from bachelor of nursing. The majority of the staff nurses had more than 15 years of experience, and the rest of the sample their years of experienced between $5-15$ years, while the majority of nursing staff more than 15 years of experience, and the rest of the sample had years of experience between 10 - 15 years. Also, the majority of the staff nurses attended training programs CPR-infection control followed by CPR, infection control- EGG.

When comparing mean score of staff nurses and nursing staff, the perception of the effectiveness of the nursing development programs there was statistically significant difference in the mean score of items "The follow-up to the nursing team's performance was constant by the training team." , "Attending nursing training programs Increase the patient's satisfaction", and "Attending the nursing training programs affects on increase the ability to solve problems and challenges", from investigator point of view staff nurses performance need constant follow-up by the training team and nursing staff , attending the nursing developing program increase the knowledge and increase the ability to solve problems which lead to improving the performance so the patient satisfaction improved when dealing with the knowledgeable nurse .

The present study supported by (Michal, Sasson, Alex, Amnon and Shlomo, 2014) noted that the Follow-up of nursing care given to patient more likely to perform complete care. Results reinforce the importance of follow-up of care given to the patient by nurse's supervisors' and staff development teamwork. The follow-up and treatment of patients are complex and requires cooperation between both staff development team and all health professionals. To optimal control of care and achieved patients require, trying to improve the ability to solve problems and increase the knowledge, so improve the performance and effectiveness development and better patient satisfaction achieved

The present study finding is congruent also with (Adderley, 2013) detected that the achievement of the development objectives should result in accomplishing increase the ability to solve problems and challenges and overall training goals. Also (Koichiro,2009) noted that improvements are needed, it can be accomplished through training programs such as continuous quality improvement, attending nursing training programs which Increase the patient's satisfaction through staff nurses learned to be sensitive to patients needs. Satisfying patient's needs are the first step toward having loyal patients, so hospitals that strive to ensure their patients are completely satisfied are more likely to prosper through attending nursing training programs.

Regarding the perceptions of the effectiveness of the nursing development programs on the nursing performance. the present study finding showed statistically significant difference in the mean score of item "It increases the leadership skills." this finding because nursing development programs improve the ability to carry responsibility which increases the leadership 
capacity of nurses to advance health and lead to changes, but the development programs mainly concerned to improve the nursing performance through increase the knowledge so need more demonstration of the leadership competencies, Professional Success, Conflict Management to improve the leadership skills and overall performance

The study finding is congruent with (ANA, 2015) concluded that the development of skills performance critical for success is often overlooked and new nurse managers struggle during their role transition from a clinical provider to nursing leadership. Development programs help to achieve the highest potential performance, the empower nurses are professional through competent leaders in healthcare by a variety of educational and advocacy activities to improve the performance, work increases the leadership capacity of nurses to advance health and lead changes. Nursing development programs provide enhancements opportunities through resources that focus on the individual nurse, leadership competencies, professional success, patient care environments, conflict management techniques and personal development to become an exceptional charge nurse and achieved the standard of performance.

Regarding perceptions of the effectiveness of nursing development Programs on documents and recordings. the present study finding showed statistically significant difference in the mean score of items, "There is a noticeable improvement in the nursing recordings after attending training programs " \& "It Improve the nursing documentation to increase safety and legal protection" and " It trains participants on how to control documents " and the total mean score, from investigator point of view as member of the hospital quality team, the development programs should contain documentation skill and increase the integration of documentation requirements to improve the nursing safety and legal protection and this need follows up to ensure adhered to the standard while staff nurses accept any standard of development.

The present study finding is congruent with (UK Essays 2008) stated that Documentation is one of the vital components of ethical and safety required and should be included in staff development programs. Improve the quality nursing writes of documentation chronicling and sequentially by time for safe and effective nursing practices that provide a comprehensible image of the client health status and their outcomes. Whether the documentation is in electronic or written format, hence documentation communicates the nurse observations, decisions, and outcomes for the client. Nursing care documentation instructions for the direct nursing activity that ensures the evidence for the provision of nursing care and continuity of care, the quotation indicates that for every event and record it is very important to do as evidence so that the staff would legally be safe. Moreover, nursing care provides good and healthy communication between the staff and the patient and further this provides the good continuity of care to the patient. If nursing care wasn't documented, it wasn't done. This revealed that in the clinical setting, if the documentation is not complete, then the work will be count incomplete.

The result of the present study also supported by (Ning Wang, David Hailey \& Ping $\mathrm{Yu}, 2011)$ who noted that the documentation is a communication tool for exchange of information stored in records between nurses and other caregivers. Quality nursing documentation promotes structured, consistent and effective communication between caregivers and facilitates continuity and individuality of care and safety of patients; in addition, nursing documentation can be used for other purposes such as quality assurance, legal purposes, health planning, allocation of resources and nursing development and research. so for quality assurance ,the development programs should 
contain documentation skill and requirements to improve the legal protection and standard performance.

\section{Conclusion}

The Staff nurses had highest perception of all dimension, while the nursing staff had the lowest perception of the effectiveness of development programs, and There was statistical significant between staff nurses and nursing staff in perceptions.

\section{Recommendation}

To staff development team: - arrange regular staff development courses to update the staff knowledge, skills and performance and providing guidance and published the references. Added management training programs as (leadership skills training, Decision-making and problem-solving training, trains participant how to control documents) to staff development program to improve staff nurses management skills. \& Follow-up the nursing staff's performance by the training team after staff development programs to ensure staff development effectiveness

To nursing administration: Provide enough facilities, supplies, and equipment to enable the staff to practice what they were learned safely and efficiently for further development. Raising nurses' awareness regarding the importance of being knowledgeable and skillful in their working field and empower them for development. Correlate attending staff nursing development programs to the final appraisal of the staff performance \& upgrading and promotion

\section{Reference}

Abas, A., and Mohammed, W., (2013). effectiveness of continuing nursing education program on nursing staff, knowledge at kidney transplantation units in Baghdad teaching hospitals, Iraqi National Journal of Nursing Specialties, vol. 26 (1). Retrieved from http://www.iasj.net/iasj?func=fulltext\&aI $\mathrm{d}=76722$

Aboshaiqah, A., (2011, Oct 18), E-Learn: World Conference on E-Learning in Corporate Government, Healthcare, and Higher Education, Barriers for Continuing Professional Development for Nurses at King Fahad Medical City, Saudi Arabia, in Honolulu, Hawaii, USA,pp.1A,2A.

Adderley, U. (2013) Doctor degree of Philosophy University of York , Department of Health Sciences March, Community Nurses' Judgment and Decision Making for the Management of Venous Leg Ulceration retrieved from : http://etheses.whiterose.ac.uk/4138/ 1/PhD_Thesis_Una_Adderley_05.

Aghabarary ,M., Hoseini,N., Sharifi,A., Nayeri,N., Farahani,A. (2012 , March) Nursing documentation in nursing homes - state-of-the-art and implications for quality improvement, Issue Volume 18 , Issue 1 , pages $72-81$

Aghayar S., (2005) Staff Satisfaction means customer satisfaction.tadbir; 16(4):96-99

Alberta, (2014) , Employers: Eight Great Ways to Develop Your Employees, ALIS, eProducts \&Services Retrieved from: https://alis.alberta.ca/ep/eps/tips/tips.html ?EK=8784

Allen (2014), Types of Training and Development, Retrieved from: http://www.allencomm.com/2014/11/alle n-named-top-training-company-ingamification/ 
American Nurses Association, (2014).nurses for healthier

tomorrow, staff nurses retrieved from: http://www.nursingworld.org

American Nurses Association, (2015). Nursing world, staff nurses retrieved from:

http://nursingworld.org/MainMenuCategories/ ThePracticeofProfessionalNursi ng/Leadership

American Nurses Association,(2014).Nursing World ,What is Nursing ? Retrieved from: http://www.nursingworld.org/especiallyforyou /what-is-nursing American Nurse Association

Mizell, H.,(2010):Why professional development matters retrieved from:

www.learningforward.org/advancing/whypdm atters.cfm

Medical center, (2013). Departments of Nursing | NYU Langone Medical Center | 550 First Avenue, New York, Retrieved from: http://www.nursing.med.nyu.edu/researchquality/nursing-quality-and-performanceimprovement

Scott, R (.2006), Legal Aspects of Documenting Patient Care for Rehabilitation Professionals, $3^{\text {rd }}$ Ed, pp.110-125

Sherman,F.,(2014)Talent Management, What Is the Definition of Staff Development?:Retrievedfrom: : http://www.eh ow.com/facts_5059005_definition-staffdevelopment.html

National league for nursing Accreditation commission (2004), core competencies of nurse's educator with task statement retrieved from: .http //www.nIn.org/prof. def /core competencies
Koichiro ,O., (2009) Journal of Healthcare, Management Satisfaction: Focusing on "Excellent" March/April 54:2

Southern New Hampshire,(2012), "Adult Learners". Continuing Education Retrieved from: http://www.snhu.edu/ContinuingEducation.aspx

Sophie, J., Demand, M. (2010) types of registered nurses Retrieved from: http://work.chron.com/types-registerednurses-7981.html

Steckler, r. (2012) improving communication skills among nursing students: assessing the comfort curriculum as an intervention retrieved from http://uknowledge.uky.edu/cgi/viewcont ent.cgi? article $=1006 \&$ contextSteven, w. Schmidt,(2014) the relationship between satisfaction with workplace training and overall job satisfaction, human resource development quarterly, vol. 18 , no. 4 , winter retrieved from :

STTI (2015) , Sigma Theta Tau International Honor Society of Nursing, nursingsociety.org retrieved from

: http://www.nursingsociety.org/Research/Gra nts/Pages/Grantsbydate.aspx

Sullivan, R., (2006), the competency-Based Approach to training retrived from : http://Reading room the competency Based approach to training html Sundberg, G., (2015), Pomona College, Learning Objectives retrieved from: Approved for Completion of 4 Semester Credits TRHRD-735 Field Problem in Training and Development

Ning wang, David hailey \& ping yu. (2011, January22) journal of advanced nursing, quality of nursing documentation and approaches to its evaluation: a mixed-method systematic review, 22, retrieved from: http://www.uow.edu.au/ ping/publication/wan g2011.pdf 